\title{
Morphological Evaluation of Parathyroid Adenomas and Immunohistochemical Analysis of PCNA and Ki-67 Proliferation Markers
}

\author{
Paratiroid Adenomlarında Morfolojik Değerlendirme ve \\ PCNA ile Ki-67 Proliferasyon Belirleyicileri Bakımından \\ İmmünohistokimyasal İnceleme
}

\author{
Ebru DEMiRALAY', Gülüm ALTACA², Beyhan DEMIRHAN' \\ Department of ${ }^{1}$ Pathology and ${ }^{2}$ General Surgery, Başkent University, Faculty of Medicine, ANKARA, TURKEY
}

\begin{abstract}
Objective: Parathyroid adenomas are the most common cause of primary hyperparathyroidism. Biological studies have shown that parathyroid adenomas are monoclonal proliferations. Up to date, five cell types have been identified in normal parathyroid tissues; chief cells, vacuolated chief cells, dark chief cells, oxyphil cells and transitional oxyphil cells. Most parathyroid adenomas are predominantly composed of chief cells.

In this study, we aimed to indicate the relationship between the predominant cell type in parathyroid adenomas and proliferating cell nuclear antigen, Ki-67 antigen, and serum parathormone levels and the gland weight.
\end{abstract}

Material and Method: 15 cases who had a diagnosis of parathyroid adenomas were included in the study. Histopathologically, the predominant cell type was determined in all the cases. Paraffin blocks were immunohistochemically stained with proliferating cell nuclear antigen and Ki-67.

Results: The average parathormone level of the cases was $239.52 \pm 36.61$ $\mathrm{pg} / \mathrm{ml}$ before surgery. Mean gland weight was $1.69 \pm 0.49 \mathrm{~g}$. Two of the cases showed atypical adenoma characteristics. The predominant cell type was vacuolated chief cell. Immunohistochemical investigation showed that the mean average $\mathrm{Ki}-67$ index value was $4.26 \pm 0.86 \%$. The mean proliferating cell nuclear antigen index was $93.20 \pm 45.72 / 10^{3}$. There was a meaningful relationship between gland weights and serum parathormone levels. There was no meaningful relationship between predominant cell types and serum parathormone levels, proliferating cell nuclear antigen index, and Ki-67 index. The chief cell was identified as the predominant cell type.

Conclusion: It can be concluded that parathyroid adenomas come into existence as a result of neoplastic proliferation of chief cells, especially vacuolated chief cells.

Key Words: Parathyroid adenoma, PCNA, Antigen Ki-67, Immunohistochemistry

Received : 12.11 .2010

Accepted : 10.06 .2011
ÖZ

Amaç: Birincil hiperparatiroidiye en sık neden olan etken paratiroid adenomlarıdır. Biyolojik çalışmalar paratiroid adenomlarının monoklonal proliferasyonlar olduğunu göstermektedir. Normal paratiroid dokusunda 5 hücre tipi belirlenmiştir; esas hücre, berrak (vakuole) esas hücre, koyu esas hücre, oksifil hücre, transisyonel oksifil hücre. Çoğu paratiroid adenomu baskın olarak esas hücrelerden oluşmaktadır.

$\mathrm{Bu}$ çalışmada paratiroid adenomlarındaki baskın hücre tipi ile Prolifere hücre nükleer antijeni, Ki-67 antijeni, serum parathormon düzeyleri ve bez ağırlıkları arasındaki ilişkiyi belirlemeyi amaçladık.

Gereç ve Yöntem: 2007-2010 yılları arasında paratiroid adenomu sebebiyle opere edilmiş 15 olgu çalışmaya alındı. Olgularda histopatolojik olarak baskın hücre tipi belirlendi. Parafin bloklara Prolifere hücre nükleer antijeni ve Ki-67 immünohistokimyasal boyaları uyguland.

Bulgular: Hastaların tümü kadın olup ortalama yaş $58 \pm 13,36$ olarak saptand. Operasyon öncesi ortalama parathormon düzeyleri $239,52 \pm 36,61 \mathrm{pg} / \mathrm{ml}$ idi. Bez ağırlıkları ortalama $1,69 \pm 0,49$ gr idi. Olgulardan biri lipoadenomdu. İki tanesi atipik adenom özellikleri göstermekteydi. Olgulardan 8 tanesinde baskın hücre tipi "berrak esas hücre", 6 tanesinde "esas hücre", 1 tanesinde ise "oksifil hücre" idi. İmmünohistokimyasal incelemelerde Ki-67 indeksi ortalama değeri $\% 4,26 \pm 0,86$ olarak saptandı. Prolifere hücre nükleer antijeni indeksi ortalama 93,20 $\pm 45,72 / 10^{3}$ olarak belirlendi. Bez ağırlıklarının serum parathormon düzeyleri üzerine anlamlı etkisi olduğu saptandı. Baskın olan hücre tiplerinin serum parathormon düzeyleri, Prolifere hücre nükleer antijeni indeksi, Ki-67 indeksi üzerine anlamlı etkisi olmadığı tespit edildi. Sonuç olarak çalışmamızda olguların çoğunda baskın hücre tipi esas hücre olarak saptanmıştır.

Sonuç: Paratiroid adenomlarının esas hücre, özellikle berrak esas hücrelerin neoplastik proliferasyonları sonucu meydana geldiği söylenebilir.

Anahtar Sözcükler: Paratiroid adenomu, PCNA, Ki-67 Antijeni, İmmünohistokimya

Correspondence: Ebru DEMİRALAY

Department of Pathology, Başkent University, Faculty of Medicine,

ANKARA, TURKEY

E-mail: ebrudemiralay@yahoo.co.uk Phone: +90 2165541500 


\section{INTRODUCTION}

Parathyroid adenomas are the most common cause of primary hyperparathyroidism with a rate of $75-85 \%$ and are benign hypercellular neoplasms consisting of chief cells, oxyphil cells or a mixture of these cells (1). They are usually seen in only one gland and the rest of the glands can be normal or atrophic $(1,2)$. They often develop from the lower parathyroid glands. They are macroscopically surrounded by a thin capsule and exhibit mild lobulation. Non-neoplastic parathyroid tissue is observed outside the capsule in some cases (3). Sometimes they may have pleomorphic and bizarre nuclei but vascular invasion, mitotic activity and metastasis are not observed. These cases are called 'atypical parathyroid adenoma' (1). They are called 'lipoadenoma' when glandular elements show solidarity with the population of mature adipocytes, and are called 'oxyphil parathyroid adenoma' when all or almost all of them are composed of oxyphil cells $(4,5)$. A dominance of chief cells is usually observed in parathyroid adenomas $(5,6)$. A small amount of oxyphilic cell groups can sometimes be observed.

Biological studies show that parathyroid adenomas are monoclonal proliferations and that these tumors arise from neoplastic proliferations of a single abnormal cell (2,7-9).

In our study, it was aimed to determine the relationship between proliferation activity and parathyroid hormone levels (PTH) and parathyroid cell types in parathyroid adenomas. The relationship between the predominant cell type, PCNA (Proliferating cell nuclear antigen) Labeling Index (LI), Ki-67 index and serum PTH levels in parathyroid adenomas was analyzed.

\section{MATERIAL and METHOD}

Fifteen cases who had underwent surgery for parathyroid adenoma between 2007-2010 at the Baskent University Istanbul Hospital were included in the study. Intraoperative pathological examination was performed for all the material. Weights were measured and recorded. All materials were diagnosed as parathyroid tissue during examination with light microscopy.

Tissue processing was performed to materials after the intraoperative pathological examination. Hematoxylin-eosin (H\&E) staining was performed to sections prepared from paraffin blocks. All cases were consistent with parathyroid adenoma in the examination with light microscopy. The predominant cell types were determined by examining all the material. Sections prepared from paraffin blocks were immunohistochemically stained with Ki-67 (cloneMIB-1, monoclonal mouse, DAKO) and PCNA (C 10 clone, mouse monoclonal, Novocastra) antibodies by using the peroxidase-antiperoxidase method. Tumor cells displaying positive nuclear staining among a total of 1000 cells in the areas where there was a maximum number of PCNApositive cells in the lesions was expressed as PCNA LI. The most densely stained areas were chosen for Ki-67, 100 cells were counted and the percentage of positively stained nuclei was calculated. Ki-67 labeling index was expressed as the percent of positively stained cells.

Statistical analyses were performed with the GraphPad Prism 5.0 package program in this study. In addition to descriptive statistics (mean, standard deviation) used in the analysis of data, the Mann-Whitney $U$ test was used in comparing paired groups and Spearman correlation analysis was used to analyze the relationships between groups. The results were considered significant at $\mathrm{p}<0.05$.

\section{RESULTS}

All patients were female. The mean age was 58 (47-79) years. Localization was lower left parathyroid gland in 11, upper left in 2 and lower right in 2 . The mean preoperative PTH levels of the patients was $239.52 \pm 36.61 \mathrm{pg} / \mathrm{ml}$. The mean weight of the glands was $1.69( \pm 0.49)$ gr. One of the cases was lipoadenoma and two showed atypical parathyroid adenoma features on histopathological examination (Figure 1,2). The microscopically predominant cell types were determined to be vacuolated chief cells in 8 cases, chief cells in 6 cases and oxyphilic cells in 1 case (Figure $3,4)$. The dark chief cell and transitional oxyphilic cell types were not found (Table I).

PCNA was positive in all cases on immunohistochemical examination and PCNA LI was determined as $93.20 \pm 45.72$ /103. PCNA staining was not observed in normal parathyroid tissue outside the capsule. Ki-67 index in all cases was $4.26 \pm 0.86 \%$.

PTH level in adenomas predominated by vacuolated chief cells was $254.76 \pm 66.17 \mathrm{pg} / \mathrm{ml}$ while it was $228.78 \pm$ $31.82 \mathrm{pg} / \mathrm{ml}$ in adenomas predominated by chief cells and no statistically significant difference was found between them ( $\mathrm{p}=0.754)$. PCNA LI was determined to be $69.25 \pm$ $22.02 / 10^{3}$ in adenomas predominated by vacuolated chief cells and $138.83 \pm 113.72 / 10^{3}$ in adenomas predominated by chief cells $(\mathrm{p}=0.796)$. Ki-67 index was $4.25 \pm 1.03 \%$ $(\mathrm{p}=0,905)$ in adenomas predominated by vacuolated chief cells and $4.28 \pm 1.52 \%$ in adenomas predominated by chief cells. No significant difference was found between these values according to the predominant cell types (Figure 5). 


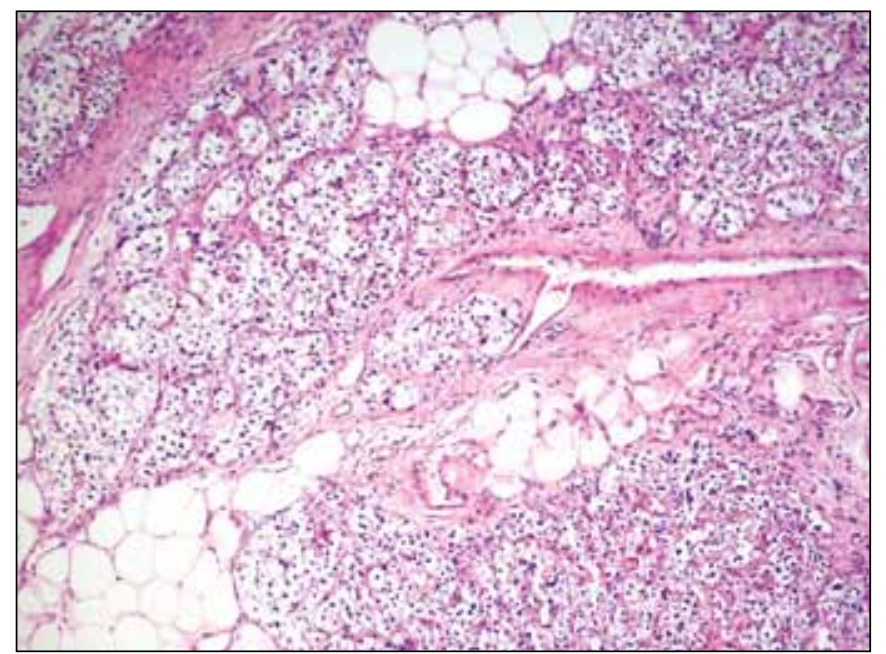

Figure 1: Lipoadenoma composed of vacuolated chief cells and mature adipocyte populations (H\&E; x100).

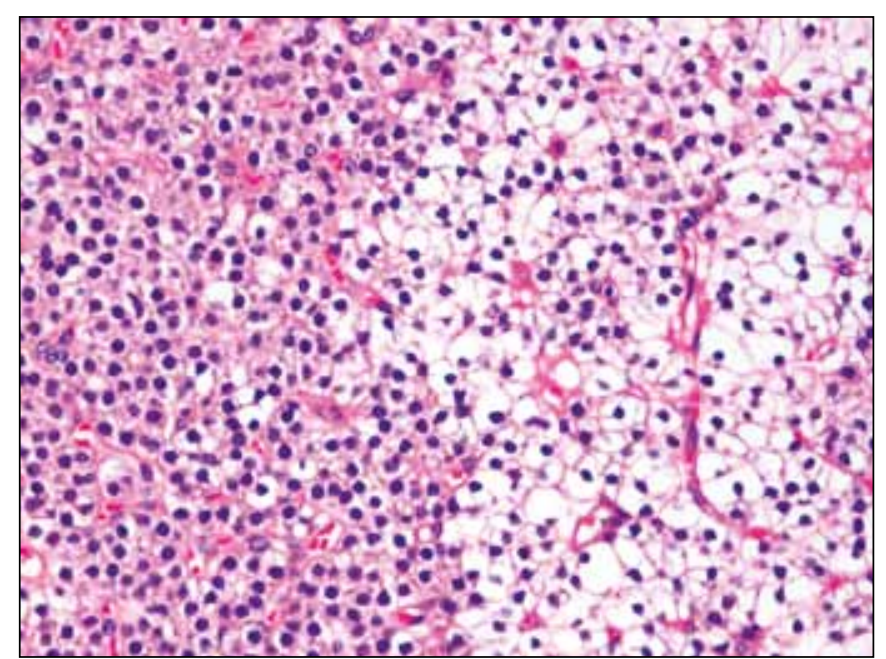

Figure 3: Chief cells (left side) and vacuolated chief cells with vacuolated cytoplasm (right side) (H\&E; x200).

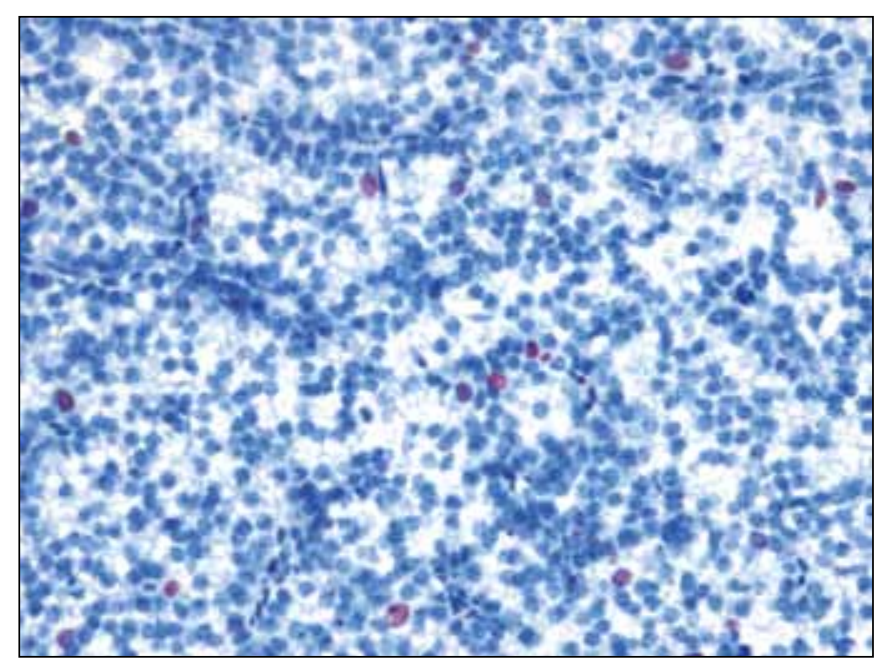

Figure 5: Ki-67 positive cells with dark red nucleus in parathyroid adenoma (x400).

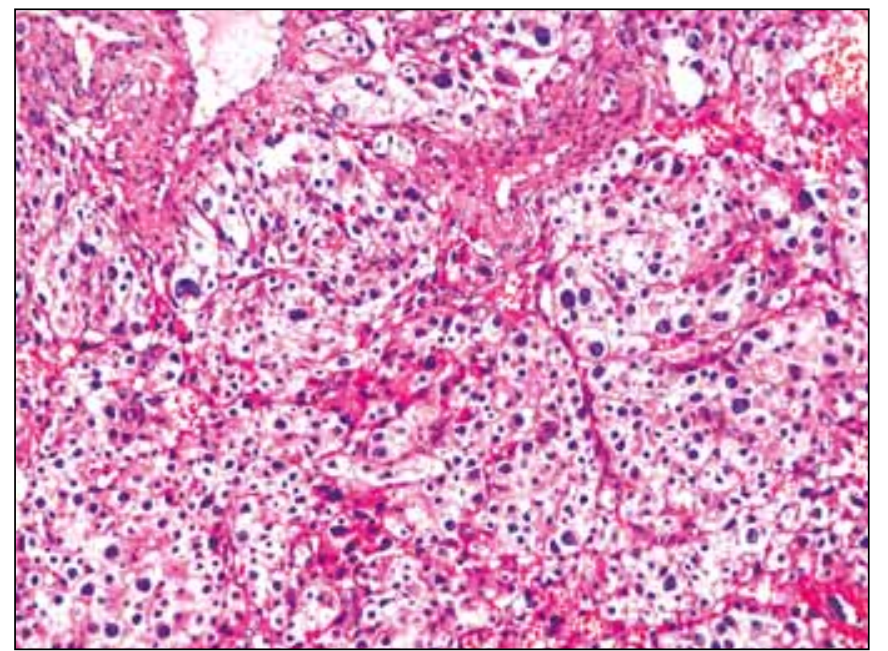

Figure 2: Atypical parathyroid adenoma; cells with pleomorphic nucleus, eosinophilic cytoplasm and oxyphil cell groups in between (H\&E; x200).

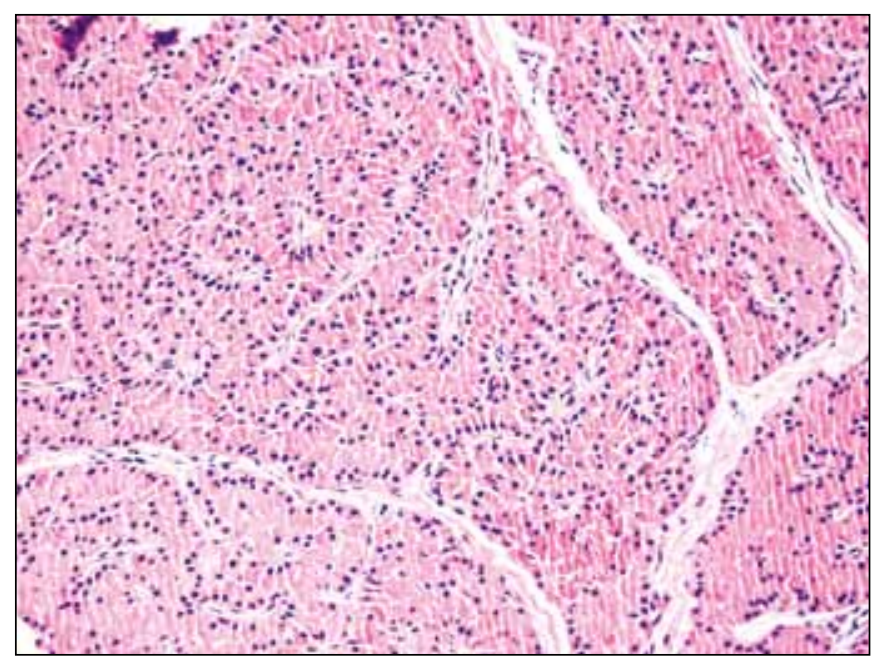

Figure 4: Oxyphil cells with large eosinophilic cytoplasm and peripheral nucleus (H\&E; x100).

The weight of the glands were found to have a significant effect on PTH levels with PTH levels increasing as the weight of the gland increased (Spearman $r=0.5821 ; \mathrm{p}=0.02$ ). The highest PCNA LI values were found in two cases showing atypical parathyroid adenoma morphology with one predominated by vacuolated chief cells and the other one with chief cells (Figure 6).

No correlation was found between PCNA LI and serum PTH levels ( $r=-0,087 ; p=0,756)$ (Figure 7).

\section{DISCUSSION}

Five cell types have been identified in normal parathyroid tissues; chief cells, vacuolated chief cells, dark chief cells, oxyphil cells and transitional oxyphil cells. Dark chief cells 


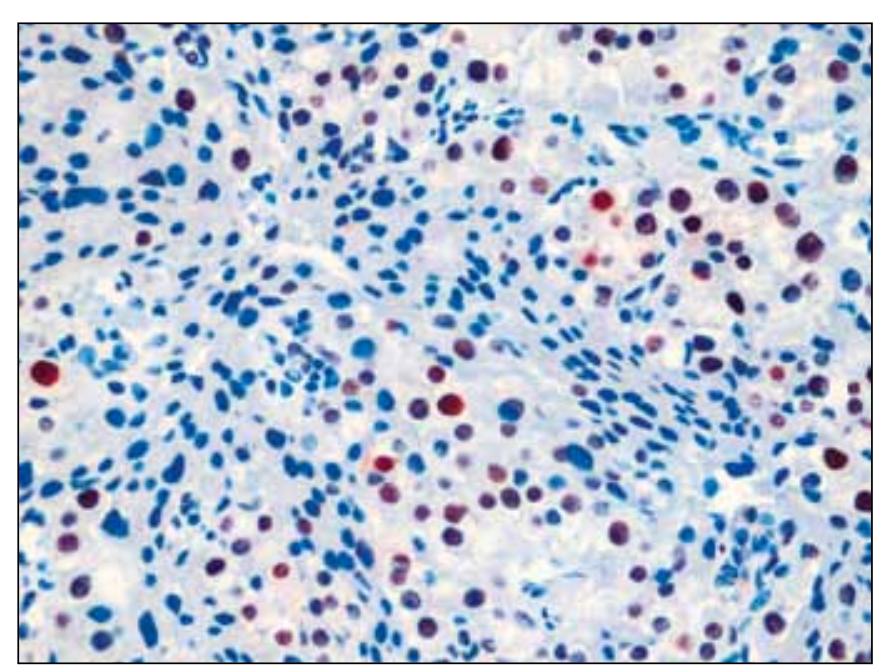

Figure 6: PCNA immunoreactivity in atypical parathyroid adenoma case $(\mathrm{x} 400)$.

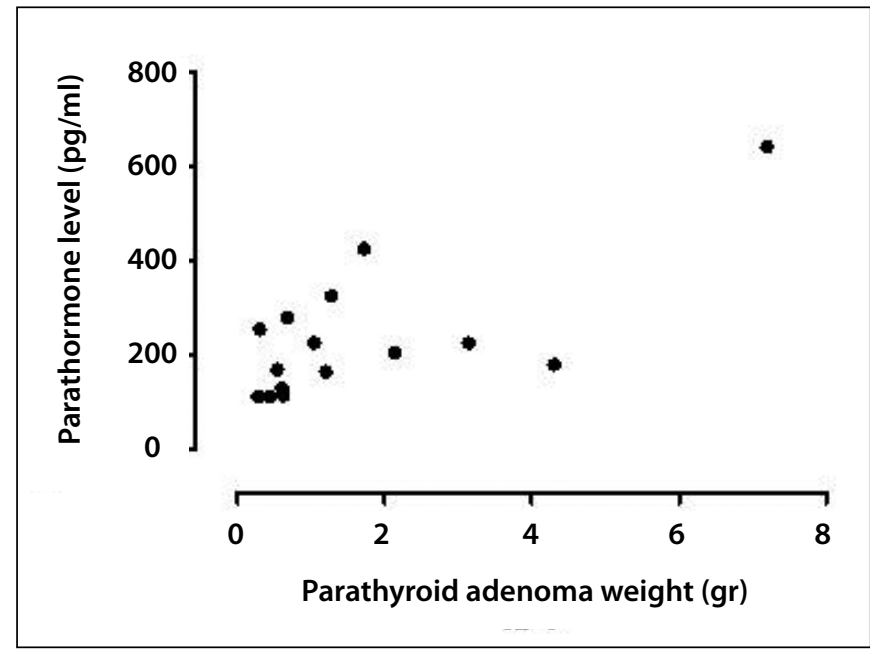

Figure 7: The relationship between weight of parathyroid adenoma and serum parathyroid hormone levels.

Table I: Clinical, morphological and immunohistochemical characteristics

\begin{tabular}{|c|c|c|c|c|c|c|}
\hline CASE & AGE & WEIGHT(gr) & CELL & PCNA LI & Ki-67 & PTH (pg/ml) \\
\hline 1 & 54 & 1.2 & CC-VCC & 24 & 7 & 166.3 \\
\hline 2 & 50 & 2.14 & VCC-CC & 14 & 4 & 206.4 \\
\hline 3 & 79 & 0.3 & CC-VCC & 10 & 1 & 256.3 \\
\hline 4 & 63 & 1.04 & VCC & 160 & 7 & 227.7 (LA) \\
\hline 5 & 27 & 4.3 & OC-CC & 11 & 1 & 182.1 \\
\hline 6 & 62 & 7.20 & VCC-OC & 491 & 1 & 643.7 (AA) \\
\hline 7 & 61 & 0.28 & VCC & 74 & 2 & 114.2 \\
\hline 8 & 53 & 0.68 & CC & 30 & 2 & 282 \\
\hline 9 & 77 & 0.54 & VCC-OC & 30 & 9 & 170.7 \\
\hline 10 & 47 & 3.14 & CC-VCC & 19 & 1 & 227.9 \\
\hline 11 & 50 & 1.28 & CC-VCC & 707 & 11 & 326.7 (AA) \\
\hline 12 & 73 & 0.62 & VCC-CC & 157 & 1 & 116.2 \\
\hline 13 & 61 & 1.72 & VCC & 11 & 6 & 427.2 \\
\hline 14 & 66 & 0.44 & CC-VCC & 43 & 7 & 113.5 \\
\hline 15 & 48 & 0,60 & VCC-CC & 17 & 4 & 132 \\
\hline
\end{tabular}

CC: Chief Cell, VCC: Vacuolated Chief Cell, OC: Oxyphil Cell, LA: Lipoadenoma, AA: Atypical Parathyroid Adenoma, PTH: Parathormon

have a more narrow cytoplasm and darker nucleus than normal chief cells. Vacuolated chief cells are smaller than normal chief cell, have a peripherally located nucleus and a clear, large, vacuolated cytoplasm. Oxyphilic cells are large and have an eosinophilic cytoplasm. Transitional oxyphilic cells are smaller than classical oxyphilic cells and have a cytoplasm lighter in color (7).

Shannon et al. have investigated the secretory cycle of chief cells ultrastructurally and found that large cells are in the rest phase while dark chief cells are in the vesiculation phase. These findings demonstrate that dark chief cells have higher hormone secretion. The proliferative activity of oxyphilic cells was determined to be the same as or higher than chief cells (10).

Immunohistochemical PCNA staining of adenomas, secondary hyperthyroidism cases and normal parathyroid tissue cells in studies showed PCNA LI to be highest in adenomas $(7,11)$. It was highest in vacuolated chief cells and lowest 
in dark chief cells according to the cell types. Dark chief cells have the most active hormone secretion but are a cell type in the G0 phase of the proliferation cycle and have low PCNA LI. Oxyphilic cells have a high proliferation index similar to vacuolated chief cells. Transitional oxyphilic cells have higher PCNA LI values than classical oxyphilic cells (7).

PCNA LI was determined to be $70 \pm 68 / 10^{3}$ in chief cells and $14 \pm 0 / 10^{3}$ in transitional oxyphilic cells while staining was not observed in other cell types in a study conducted by Yamaguchi et al. They found a few PCNA positive cells in normal parathyroid tissue outside the capsule (7). PCNA positive cells were not observed in normal parathyroid tissue in studies by Larian et al. and Loda et al. and in our study $(2,11)$.

No correlation was observed between PCNA LI and serum PTH levels according to cell types in our study. This also suggests that there is no relationship between hormone secretion and the proliferation activity of cells. However, this was not considered statistically significant due to low number of our cases and the lack of dark chief cell and transitional oxyphilic cell types.

PCNA LI was $45.8 \pm 33.1$ in a study of 12 cases and a correlation was found between PCNA LI and serum PTH levels (12). No correlation was found between PCNA LI and serum PTH levels in our study. The highest PCNA LI level was observed in atypical adenomas and the serum parathyroid hormone levels was also higher in these two cases. However, finding high serum parathyroid hormone levels in another case that was also determined to have very low PCNA LI supports the lack of a relationship between proliferation activity and hormone secretion of cells and suggests that atypical parathyroid adenomas should be addressed in a different category.

One of our patients showed lipoadenoma features. Parathyroid lipoadenomas are rare in the literature. Histologically, more than $50 \%$ of the lesion is composed of adipocytes. Clinically, they show characteristics similar to classical parathyroid adenomas (4). The mean serum PTH level was $239.52 \pm 36.61$ in our case. PCNA LI and $\mathrm{Ki}-67$ index were above the mean value of the study. Histopathologically, they were composed of adipocyte populations as well as vacuolated chief cells.

A significant relationship was found between the Ki-67 index and serum PTH levels in a study carried out by Gozu et al. (13). Ki-67 expression in carcinoma is significantly higher than in adenoma. Ki-67 proliferation index was found to be $2 \%$ in adenoma and $25 \%$ in carcinoma in studies. This also shows that $\mathrm{Ki}-67$ can be helpful in lesions that are difficult to differentiate between adenoma and carcinoma $(1,14)$.

Observing higher Ki-67 expression in adenoma than normal parathyroid tissue indicates that adenomas are clonal proliferations (8).

Clonal analyses have shown that parathyroid adenomas are monoclonal $(2,8,9)$. All adenomas were determined to be monoclonal and normal parathyroid tissue to be polyclonal with the phosphoglycerate kinase gene in studies of Larian et al. (2).

A study has found positive correlation between the weight of the parathyroid adenoma and serum $\mathrm{Ca}++$ concentrations but no relation was determined with serum parathyroid hormone levels (15). Similar to our study, many studies have determined a positive correlation between the weight of the adenoma and serum PTH levels (16-18).

In conclusion, the predominant cell type was determined to be the chief cell in the majority of cases in our study. It can be said that the majority of parathyroid adenomas arise from neoplastic proliferations of vacuolated chief cells Larger series are required to determine the relationship between cell types and serum PTH levels.

\section{REFERENCES}

1. Stojadinovic A, Hoos A, Nissan A, Dudas ME, Cordon-Cardo C, Shaha AR, Brennan MF, Singh B, Ghossein RA: Parathyroid neoplasms: clinical, histopathological and tissue microarraybased molecular analysis. Hum Pathol 2003, 34:54-64

2. Larian B, Alavi S, Roesler J, Namazie A, Blackwell K, Calcaterra TC, Wang MB: The role of hyperplasia in multiple parathyroid adenomas. Head Neck 2001, 23:134-139

3. Ghandur-Mnaymneh L, Kimura $\mathbf{N}$ : The parathyroid adenoma: a histopathologic definition with a study of 172 cases primary hyperparathyroidism. Am J Pathol 1984, 115:70-83

4. Chow LS, Erickson LA, Abu-LebdehHS, WermersRA: Parathyroid lipoadenomas: a rare cause of primary hyperparathyroidism. Endocr Pract 2006, 12:131-136

5. Gurrado A, Marzullo A, Lissidini G, Lippolis A, Rubini D, Lastilla G, Testini M: Substernal oxyphil parathyroid adenoma producing PTHrP with hypercalcemia and normal PTH level. World J Surg Oncol 2008, 6:24

6. Fleischer J, Becker C, Hamela-Bena D, Breen TL, Silverberg SJ: Oxyphil parathyroid adenoma: a malignant presentation of a benign disease. J Clin Endocrinol Metab 2004, 89:5948-5951

7. Yamaguchi S, Yachiku S, Morikawa M: Analysis of proliferative activity of the parathyroid glands using proliferating cell nuclear antigen in patients with hyperparathyroidism. J Clin Endocrinol and Metab 1997, 82:2681-2688

8. Hadar T, Shvero J, Yaniv E, Ram E, Shvili I, Koren R: Expression of p53, Ki-67 and Bcl-2 in parathyroid adenoma and residual normal tissue. Pathol Oncol Res 2005, 11:45-49 
9. Shan L, Nakamura M, Nakamura Y, Inoue D, Morimoto S, Yokoi T, Kakudo K: Comparative analysis of clonality and pathology in primary and secondary hyperparathyroidism. Virchows Arch 1997,430:247-251

10. Shannon WA, Roth SI: An ultrastructural study of acid phosphatase activity in normal, adenomatous and hyperplastic (chief cell type) human parathyroid glands. Am J Pathol 1974, 77:493-506

11. Loda M, Lipman J, Cukor B, Bur M, Kwan P, DeLellis RA: Nodular foci in parathyroid adenomas and hyperplasias: An immunohistochemical analysis of proliferative activity. Hum Pathol 1994, 25:1050-1056

12. Gülkesen KH, Kılıçarslan B, Altunbaş HA, Karpuzoğlu G: EGFR and p53 expression and proliferative activity in parathyroid adenomas. Acta Pathologica, Microbiologica et Immunologica Scandinavica 2001, 109:870-874

13. Gözü HI, Ege AG, Sargin H, Erkal F, Sönmez B, Sargin M, Murtezaoğlu M, Gezen C, Enginer T, Vural S, Karadayı N: Proliferation activity in parathyroid adenomas and its relation to the clinical parameters. Turkish Journal of Endocrinolgy and Metabolism 2006, 3:57-61
14. Erickson LA, Jin L, Wollan P, Thompson GB, van Heerden JA, Lloyd RV: Parathyroid hyperplasia, adenomas, and carcinomas: differantial expression of p27Kip1 protein. Am J Surg Pathol 1999, 23:288-295

15. Kutlutürk F, Kubat Üzüm A, Mert M, Azezli A, Orhan Y, Aral F, Erbil Y, Kapran Y, Özbey N: Primer hiperparatiroidide, paratiroid adenom ağırlığı ile preoperatif biyokimyasal parametreler arasındaki ilişki. İstanbul Üniversitesi İstanbul Tip Fakültesi Dergisi 2006, 69:32-35

16. Bindlish V, Freeman JL, Witterick IJ, Asa SL: Correlation of biochemical parameters with single parathyroid adenoma weight and volume. Head Neck 2002, 24:1000-1003

17. Williams JG, Wheeler MH, Aston JP, Brown RC, Woodhead JS: The relationship between adenoma weight and intact (1-84) parathyroid hormone level in primary hyperparathyroidism Am J Surg 1992, 163:301-304

18. Locchi F, Tommasi M. Brandi ML, Tonelli F, Meldolesi U. A controversial problem: is there a relationship between parathyroid hormone level and parathyroid size in primary hyperparathyroidism. Int J Biol Markers 1997,12:106 -111 